\title{
Comparing engagement by migrants in domestic and in country-of-origin political activities across European cities
}

\author{
Katia Pilati ${ }^{1}$ - Barbara Herman ${ }^{2,3}$
}

Published online: 16 July 2018

(C) The Author(s) 2018, corrected publication 2019

\begin{abstract}
This article aims to investigate levels of migrants and second generations' engagement in country-of-origin political activities and in domestic political activities. Using data from a population survey of individuals of migrant origin in ten European cities undertaken in 2004-2010, we examine both individual and contextual characteristics shaping engagement in one and in the other scope of action. Findings show that migrants and second generations tend to engage in an equal number of domestic and country-of-origin political activities. Engagement in country-of-origin political activities only is fully compatible with a trajectory of political integration in the countries of settlement, opposing the view that migrants may contribute to build or live in a "separate" society. Finally, the results show that contextual opportunities affect chances to engage in one or in the other scope of action. In particular, easy access to residence permits favours engagement in domestic political activities and discourages engagement in country-of-origin political activities. This suggests that migrants and second generations' engagement in country-of-origin political activities may be a reaction to the limited opportunities of integration offered by the residence countries.
\end{abstract}

Electronic supplementary material The online version of this article (https://doi.org/10.1057/ s41269-018-0102-4) contains supplementary material, which is available to authorized users.

Katia Pilati

katia.pilati@unitn.it

1 Department of Sociology and Social Research, University of Trento, Via Verdi 26, 38122 Trento, Italy

2 Chargée de Missions - CRAcs, Centre Bruxellois d'Action Interculturelle, 24, Avenue de Stalingrad, 1000 Brussels, Belgium

3 Group of research on Ethnic Relations, Migration and Equality (GERME), Université Libre de Bruxelles (ULB), Brussels, Belgium 
Keywords Transnational politics $\cdot$ Domestic politics $\cdot$ Political participation $\cdot$ Immigration $\cdot$ Europe $\cdot$ Integration

\section{Introduction}

Studies examining migrants' political engagement have rapidly increased in the last few years (Kastoryano and Schader 2014). On the one hand, the literature has focused on migrants' political integration in countries of residence by examining political behaviours such as participation in local administrative elections, political contacting or protest actions (Koopmans et al. 2005; Aleksynska 2011; de Rooij 2012; Gonzalez-Ferrer 2011; Morales and Pilati 2011; Heath et al. 2013; Just and Anderson 2014; Voicu and Comşa 2014). On the other, studies have focused on migrants' political activities oriented to their origin countries, like external voting. The latter have been mostly investigated under the umbrella of transnational studies (Portes et al. 1999, 2007; Levitt 2001; Bauböck and Faist 2003; Smith 2008; Martiniello and Lafleur 2008; Lafleur 2013; Mügge 2016; Boccagni et al. 2015).

These two types of literature have developed quite separately one from another (Lacomba 2016). When discussed together, empirical cases have focused, at most, on single countries (Van Bochove et al. 2010; see however Chaudary 2017). However, joining these approaches is crucial given that some fear that transnational activities may contribute to a sort of a "separate" society opposing processes of immigrant integration in residence countries (Erdal and Oeppen 2013; Waldinger 2016). ${ }^{1}$ Empirical evidence on the relationship between political transnationalism and political integration in migrants' countries of residence is, indeed, not consistent. Some studies show that migrants' political transnationalism is in many cases a response to the lack of political integration in countries where migrants settle (Guarnizo and Smith 1998; Landolt 2001; Koopmans et al. 2005). Some other studies show that they are not a zero-sum game (Portes and Rumbaut 2006; DeSipio 2006; Morales and Morariu 2011; Jaulin 2015; Chaudary 2017).

Following this, this article aims to investigate both levels of migrants' engagement in political activities oriented to their country of origin, from now onwards country-of-origin political activities, part of the broader set of transnational actions (Mügge 2016), and migrants' engagement in activities oriented to the residence country, that is, domestic political activities, across European cities. Are migrants settled in European cities more likely to engage in domestic or in country-of-origin political activity? And do migrants active in domestic issues differ from migrants active in country-of-origin political activities because of different individual profiles or different opportunities of political integration in the residence country?

\footnotetext{
${ }^{1}$ We draw on relative notions of political integration that take levels of political orientations and behaviours from the majority population as the comparative standpoint from which to judge the degree to which a given society has been successful in integrating immigrants and their offspring into life (Morales 2011, p. 31).
} 
To answer these questions, we integrate insights from the literature on political transnationalism, a concept identifying situations in which migrants find themselves embedded and acting in and between two countries, the countries of origin and the countries of residence (Schiller et al. 1995; Vertovec 2004; Mouw et al. 2014), with the insights derived from the literature on migrants' political integration in the countries of residence (Koopmans et al. 2005; de Rooij 2012; Just and Anderson 2014; Pilati 2018). Our first contribution is to reinforce studies trying to combine perspectives on transnational practices with those on migrants' political integration in the residence countries (Ahmadov and Sasse 2016; Mügge 2016, p. 110; for similar studies in relation to the economic dimension, specifically remittances, cf. Carling and Hoelscher 2013). Considering both scopes of action may indeed better clarify broader processes of migrants' integration in the countries where migrants settle (Erdal 2013).

Empirically, we analyse data from a population survey undertaken in 2007-2010 on migrants and their offspring in the following ten European cities: Barcelona, Brussels, Budapest, Geneva, Lyon, London, Madrid, Milan, Stockholm and Zurich (Morales et al. 2014). The data consist of comparable random samples of individuals of migrant origin from the two or three major migrant groups in each city $(n=7944)$. In this way, and this is our second contribution, we aim to go beyond most comparative studies, especially those focused on political transnationalism, which have examined at most two or three groups in a single site (see however Jaulin 2015, Ahmadov and Sasse 2016).

\section{Factors explaining country-of-origin and domestic political activities}

In this work, we refer to political activities as those activities relating to political objects, or those activities aiming to change or to resist a particular change (for a discussion on the concept of political participation see van Deth 2014). In this vein, following a typology of political activities usual in the literature on political behaviour, migrants' political engagement in domestic activities can be examined through a variety of actions, from migrants' voting in local elections to participation in more contentious forms of action such as protests (Tam Cho 1999; Leal 2002; de Rooij 2012; Just and Anderson 2014). Studies on transnational political activities have investigated a broad variety of activities too (cf. Mügge 2016 for an overview of types of transnational political activities). Some studies have examined 'the political activities of party officials, governmental functionaries, or community leaders whose main goals are the achievement of political power and influence in the sending or receiving countries' (Portes et al. 1999, p. 221). Other scholars have examined activities by ordinary migrants (Goldring 2002; Guarnizo et al. 2003; Østergaard-Nielsen 2002, p. 21; Martiniello and Lafleur 2008; Itzigsohn and Villacrés 2008). The latter include external voting, that is, migrants' participation in country-of-origin elections, or membership in country-of-origin political parties, and monetary contributions to campaigns oriented to country-of-origin political issues (Lafleur 2013). Given that electoral participation is not the main channel of transnational politics for 
many migrants, scholars have also examined extra-electoral activities such as contributing money for projects in the country of origin or membership in home-town associations or in ethnic organizations active in issues related to migrants' country of origin (Guarnizo et al. 2003; Itzigsohn 2000; Portes et al. 2008; Pries and Sezgin 2013).

We confine our analyses to political behaviour strictly speaking, focusing on extra-electoral activities such as signing a petition, contacting politicians or joining demonstrations (see "Methods" section for the full list of items considered). ${ }^{2}$ We do not investigate voting patterns as there are a number of cities in our sample, Brussels, Budapest, Madrid and Milan, where we only have few migrants with access to voting in local or national elections of the residence countries (cf. Chaudary 2017 for analyses on migrants' intention to vote).

The literature has shown a broad number of individual and contextual characteristics which are expected to affect political activities. Below, we discuss how such factors are likely to affect engagement in domestic and/or country-of-origin political activities.

\section{Classical predictors of political engagement}

In line with the literature on political behaviour (Verba and Nie 1972, Verba et al. 1995), evidence on migrants' participation in domestic issues demonstrates that males, migrants with higher socio-economic status, in particular those who have attained high levels of education and have greater professional skills, and migrants with a stable family situation, are all more likely to engage in political activities (Brady et al. 1995; Tam Cho 1999; Leal 2002; de Rooij 2012). Such characteristics affect, in a similar way, engagement in country-of-origin political activities (Portes et al. 1999; Guarnizo et al. 2003; Smith 2008; Portes et al. 2008; Morales and Pilati 2014). Following the civic voluntarism model, CVM (Verba et al. 1995), studies have also highlighted the role of social trust and involvement in local civic institutions, specifically voluntary associations, in fostering political engagement of migrants in the residence countries (Lien et al. 2003; Ramakrishnan and Bloemraad 2008; Berger et al. 2004; Mollenkopf and Hochschild 2009; Pilati and Morales 2016). In addition, the literature on transnationalism has specifically focused on the role played by home-town or ethnic associations for migrants' engagement in transnational practices (Guarnizo et al. 2003; Itzigsohn 2000; Lacroix 2014).

\footnotetext{
${ }^{2}$ Differently from home-town associations which are considered as transnational activities by several studies (Guarnizo et al. 2003; Portes et al. 2008), we do not consider engagement in ethnic organizations as transnational activities but consider ethnic organizations as possible factors affecting transnational practices (Heath et al. 2013; Pilati and Morales 2016). It is easy for members of an ethnic organization to converge on issues pertaining to their country of origin thanks to a shared identity and to the same psychological attachments to one's own country of origin. However, activities of ethnic organizations may be also oriented to migrant communities in the residence country rather than to individuals in the country of origin. Fieldwork in European cities like Brussels, Milan and Zurich indeed shows that many ethnic and migrant organizations are often active on service delivery and provision for migrant residents (Berger et al. 2004; Jacobs et al. 2004; Eggert and Pilati 2014).
} 
Following these studies, we expect that the aforementioned classical predictors of political engagement, socio-demographic, socio-economic characteristics and involvement in organizations, accounting for different types of resources individuals are endowed with, will have a positive and significant effect on migrants' likelihood to engage in political activities, regardless of the scope of action (hypothesis 1).

\section{Immigration-related factors affecting political engagement}

As argued by Tam Cho (1999, p. 1147) classical predictors of political behaviour, especially socio-economic status (SES) ones, serve only as partial explanations for the minority and migrant population. Factors specifically related to the migration process are also important. Being second generation, fluent in the language of the residence country, holding the citizenship of the country of residence, and, for migrants, the time spent in the residence country, all contribute to greater levels of individual social, cultural and, specifically, political integration in the residence countries (Uhlaner et al. 1989; Ramakrishnan 2005; de Rooij 2012, p. 465; White et al. 2008). For instance, people who lack fluency in the residence country language are inevitably going to be restricted in their access to information about the country politics with significant consequences on their political practices (Heath et al. 2013, p. 41). The lack of citizenship has also been found to be a major barrier to participation in domestic politics (Bloemraad 2006) as well as in transnational one (Guarnizo et al. 2003). Furthermore, because of Islamophobia, differences in Church-state relationships and lower recognition of Islam in Europe, Muslim migrants may have lower probabilities to participate (Bleich 2009; Eggert and Giugni 2011; Statham and Tillie 2014). The level of discrimination experienced by many migrants may, in turn, also trigger a reactive form of mobilization in the residence countries' politics (Rim 2009). This may be linked to the development of feelings of exclusion towards the place of residence among people who experienced discrimination (Ramakrishnan 2005).

The characteristics related to processes of socio-cultural integration in the residence country have shown different and inconsistent effects on transnational political actions. Guarnizo et al. (2003) argue that longer periods of residence increase migrants' stability and heighten migrants' political engagement in issues related to their country of origin, in line with a complementarity perspective (Chaudary 2017 , p. 4). Other scholars argue that factors accounting for processes of social and cultural integration in the residence country tend to have either no significant effect or a negative impact on political engagement in country-of-origin activities (Ahmadov and Sasse 2016). For instance, Morales and Pilati (2014) find that the length of stay has a negative impact on transnational political attitudes and voting of Ecuadorians in Italy and Spain, in line with a resocialization hypothesis (Waldinger 2008; Chaudary 2017). Second generations show a periodical and occasional nature of transnational behaviour (Fokkema et al. 2012, p. 119).

Following these studies, we expect that immigration-related characteristics, in particular, those accounting for high levels of socio-cultural integration (like fluency in the residence country language, being citizens of the country of residence 
and, for migrants, length of stay), are all likely to increase migrants' chances to engage in domestic political issues. In turn, the impact of socio-cultural integration on migrants' chances to engage in country-of-origin political activities may be significant. However, due to prior inconsistent results, we do not advance a specific direction of the effect (hypothesis 2).

\section{Contextual factors affecting political engagement}

Migrants may also engage in different scopes of action because of different opportunities of participation provided by the context where they live. The literature has shed light on the role of some characteristics of the institutional contexts of the residence country, broadly acknowledged as the political opportunity structure (POS), and of some characteristics of origin countries, like allowing dual citizenship, in affecting migrants' chances to engage in the political sphere. Concerning the characteristics of the residence countries, scholars have principally examined the role of the citizenship regimes, that is, the laws and policies that each country sets out for the acquisition of citizenship. These include, for example, the number of years required to obtain citizenship after marriage with a citizen of the residence country or the number of years of residence required to migrants before obtaining citizenship in the residence country. Scholars have also highlighted the impact of discursive opportunities (Cinalli and Giugni 2016), the role of public opinion (Just and Anderson 2014) and of the residence regimes emphasizing that countries differ in the conditions necessary to obtain a short or a long permit to stay (Gonzalez-Ferrer 2011). Studies advance that the more open policies, laws and rules of the residence countries are to migrants' integration, the more opportunities migrants have to participate in domestic political issues. In contrast, closed political opportunity structures lower migrants' chances of advancing collective claims and engaging in political activities (Koopmans et al. 2005; Cinalli and Giugni 2011). In contexts with closed political opportunities, migrants tend to have limited access to resources necessary to engage in politics as they have lower upward mobility, limited political legitimation and lower possibilities to share broad collective identities based on crosscutting ties (Pilati 2016). Contextual opportunities also affect how much political engagement will be transnational in orientation (Bauböck 2003; Martiniello and Lafleur 2008; Bermudez 2009; Lafleur and Sánchez-Domínguez 2015; Jaulin 2015; Ahmadov and Sasse 2016). However, the direction of the effect is not consistent across studies. On the one hand, some researches show that residence countries favouring migrants' integration foster migrants' political transnationalism (Portes and Rumbaut 2006; DeSipio 2006; Morales and Morariu 2011; Jaulin 2015). On the other, studies show that migrants' political transnationalism is in many cases a response to the lack of integration in countries where migrants settle, therefore, of closed political opportunities. In line with this hypothesis, transnational activism can function as a compensatory mechanism of status loss due to a negative context of reception (Guarnizo and Smith1998; Landolt 2001; Koopmans et al. 2005). Following these studies, we 
expect that the more open the context of the residence countries is to migrants' integration, the higher the likelihood for migrants to engage in domestic political issues. We also expect that the context of the residence country affects migrants' engagement in country-of-origin political activities although the direction of the effect is not clear (hypothesis 3).

\section{Methods}

\section{Data source}

The empirical analysis makes use of micro data from a population survey carried out in 2006-2010 in ten European cities: Barcelona, Brussels, Budapest, Geneva, London, Lyon, Madrid, Milan, Stockholm and Zurich (Morales et al. 2014). Surveys were administered either in migrants' language of their country of origin or in the language of the residence country. In each city, the surveys were conducted on probability samples of migrants and second generations, focusing in most cities on three different migrant-origin groups: in Budapest, Chinese, ethnic Hungarian immigrants and a mixed group of immigrants originating from Muslim countries; in Barcelona and Madrid, Ecuadorians, other Latin American Andean migrants and Moroccans; in Brussels Moroccans, Turks and Congolese; in Geneva, Italians and Kosovars; in Zurich, Turks, Kosovars and Italians; in Milan, Filipinos, Egyptians and Ecuadorians; in London, Bangladeshi, Pakistani and Indians; in Lyon, Algerians, Moroccans and Tunisians; and in Stockholm, Chileans and Turks.

Following the research design, the groups share some common features as each city included at least one group of long-standing immigration, one of more recent arrival as well as one of Muslim background. Other characteristics of the migrant groups studied vary among the cities. In terms of immigration flows, post-war immigration characterized the Swiss cities, London and Lyon, while most migration flows to the Spanish cities, Budapest and Milan have taken place at the end of the eighties and, for certain groups like Ecuadorians, essentially after 2000. Furthermore, some migration flows are linked to countries' colonial past (London, Lyon, Brussels and the Spanish cities), while other cities show more heterogeneous migration flows like Milan, or are characterized by specific ethnic groups like ethnic Hungarians in Budapest and European migrants in Switzerland.

Sampling and interviewing procedures of individuals of migrant origin changed across the cities. For instance, in some cities extracting samples of individuals from the population registers was feasible (e.g. in Budapest, the Spanish cities and in Stockholm). In other cities, the lack of a reliable sampling frame required different sampling strategies (e.g. focused enumeration in London, geographical sampling in Milan, random dialling in Lyon and the Swiss cities). The surveys were jointly designed and are equivalent, and sometimes identical in most other aspects, and therefore, the results are comparable (see Palacios and Morales (2013) for full technical details of the surveys). 
The total sample in each city is a random sample stratified by ethnic origin composed of at least 250 individuals for each migrant group. The migrant sample we analyse $(N=7944)$ includes documented individuals of migrant origin, including migrants and their descendants, that is second or third generation. All the individuals selected had to have been present in the cities for at least 6 months prior to the interview, and to be at least 15 years old.

\section{Dependent variables}

We analyse one dependent variables accounting for migrants' political engagement in extra-electoral activities. Extra-electoral political activities include the following items: contacted a politician; contacted a local or national government official; worked in a political party; worked in a political action group; wore or displayed a badge, sticker or poster; signed a petition; took part in a public demonstration; boycotted certain products; deliberately bought certain products for political reasons; donated money to a political organization or group; took part in a strike; contacted the media; contacted a solicitor or a judicial body for non-personal reasons. The variable is a multinomial variable. This variable is assigned 0 if migrants did not engage in any activity in the 12 months prior to the interviews; 1 is assigned to migrants who only engaged in country-of-origin extra-electoral activities, that is, activities regarding people in origin countries; 2 is assigned to migrants who only engaged in domestic political activities concerning people in the residence city, region or country; 3 is assigned to migrants who engaged in both country-of-origin and domestic political activities or in activities with other scopes, namely those concerning the respondent, his/her family or friends, or the world.

We are aware of the limits of this variable: indeed our measure of country-oforigin political activities only refers to a tiny part of transnational political actions which are usually understood as relatively long-lasting networks (Mouw et al. 2014) and as an ongoing and continuously negotiated process (Iskander 2010). In addition, following most studies on transnational activities we focus on bi-national political ties although some scholars have claimed that this underestimates activities which transcend the borders of the sending and the receiving countries, like claims on human rights and environment (van Bochove 2012).

Our narrowly defined measure of transnational political engagement therefore suggests further investigation, including analyses on the relationship of political transnationalism with other transnational practices such as sending remittances or visiting countries of origin. Such deeper insights are often caught by considering a timeframe broader than that considered in this study. ${ }^{3}$ This nonetheless, we still believe that the analysis of this variable can give us important opportunities to reflect on the relationship between integration and transnationalism.

For the full details on the construction and the descriptive statistics of all the variables see Online Appendix and Table 1.

\footnotetext{
3 We thank a reviewer for pointing this out.
}

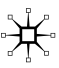




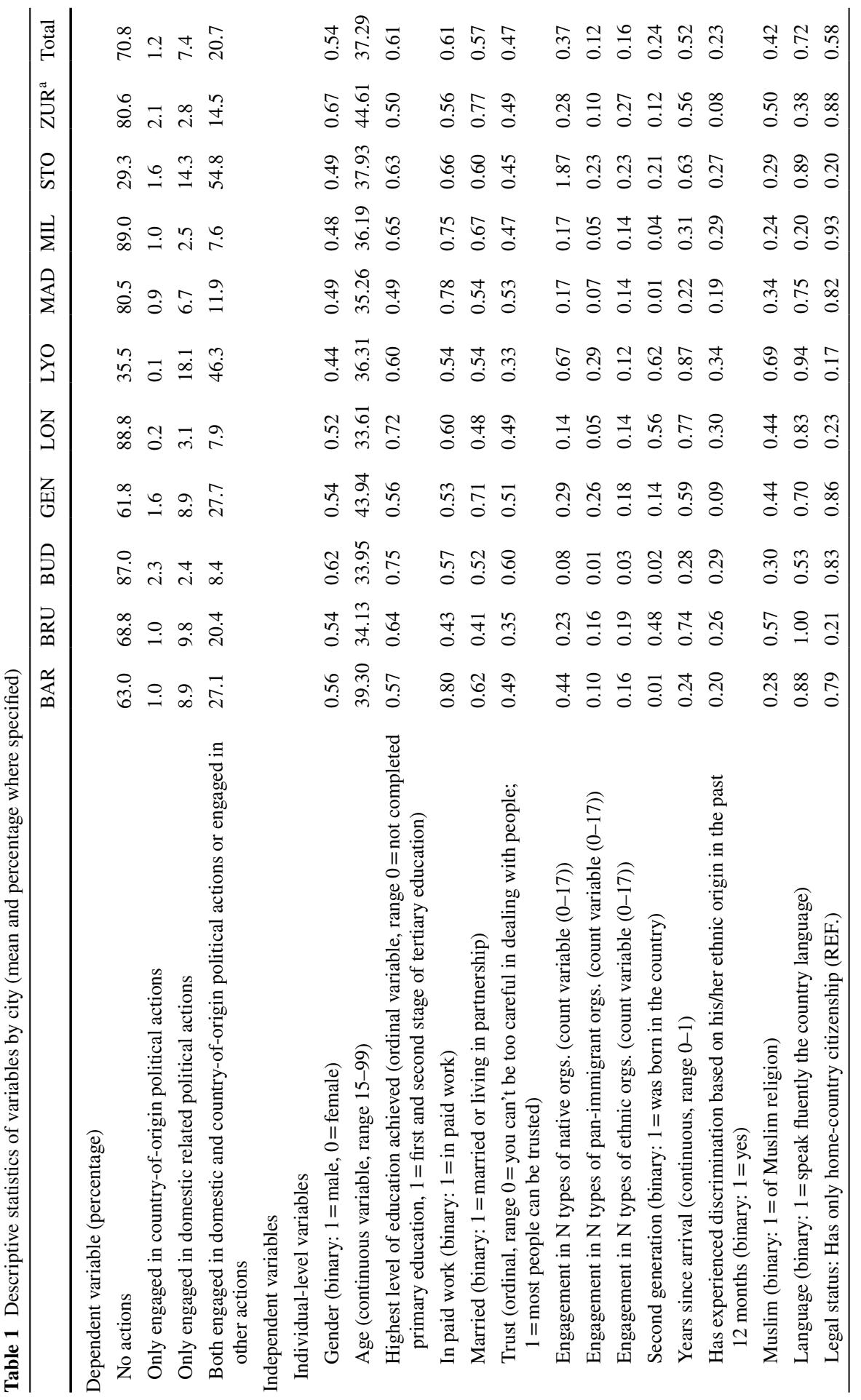




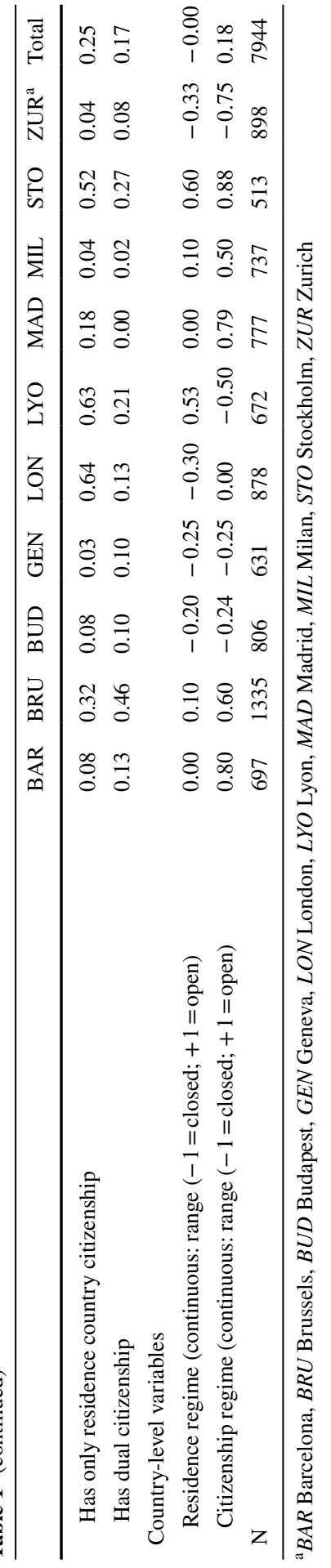

站。 


\section{Independent variables}

\section{Classical predictors of political engagement}

To test hypothesis 1 on the role of socio-economic, socio-demographic and organizational resources, we include the following variables: respondents' sex, age, educational level attained, their occupational status (being in paid work or not), civil status (being married or not), level of trust, engagement in ethnic, pan-immigrant and native organizations. ${ }^{4}$

\section{Immigration-related variables}

To test hypothesis 2, we include the following variables: migrants' generation (being first-generation migrants or second/third generations), the number of years since arrival in the residence country (for first-generation migrants), the citizenship held by migrants, proficiency of the residence country language, discrimination experienced, being Muslim. ${ }^{5}$

\section{Characteristics of the countries of residence}

We test the effect of different opportunities of integration in the residence country by considering the type of citizenship regime, that is, the rules related to the acquisition of citizenship, and the type of residence regime, that is, the conditions regulating access to permits to stay in the cities considered (Koopmans et al. 2005; Cinalli and Giugni 2011; Gonzalez-Ferrer 2011). For comparative purposes, a 3-level scoring has been used whereby the score -1 refers to the most constraining situation indicating limited opportunities in accessing citizenship and residence permits, the score +1 corresponds to the most open configuration and the score 0 applies to intermediary situations (see Online Appendix for the specific indicators used for each of these variables).

\section{Model specification}

Given the nature of the dependent variables, we test our hypotheses through multinomial logit models (see also Ahmadov and Sasse 2016 for a similar approach). For

\footnotetext{
4 Although we do not have longitudinal data and, consequently, the causal directionality between organizational involvement and political participation cannot be tested explicitly, our approach of studying political action as the outcome and organizational involvement as the 'explanatory' factor is supported by well-established scholarship that studies the effect of organizational involvement on political participation from Verba, Schlozman and Brady (1995) onwards (see, however, van Ingen and van der Meer 2015). Especially for migrants, contacts with organizations usually precede involvement in political actions given that migrants often turn to service delivery associations upon their arrival in the host countries.

${ }^{5}$ Due to the lack of data, we cannot include pre-migration variables like the region of origin or the preexisting political experience in migrants' countries of origin.
} 


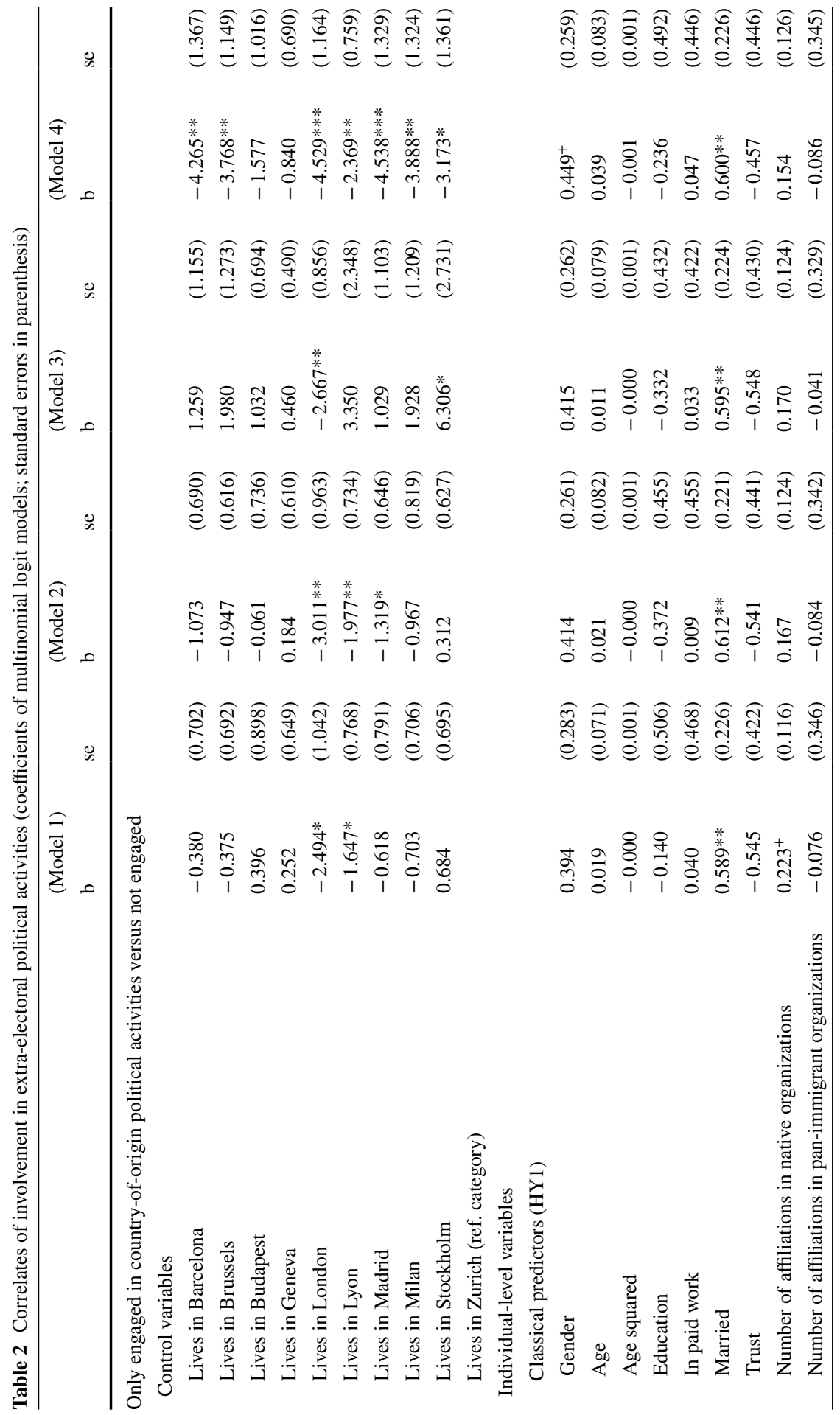

- 望- 


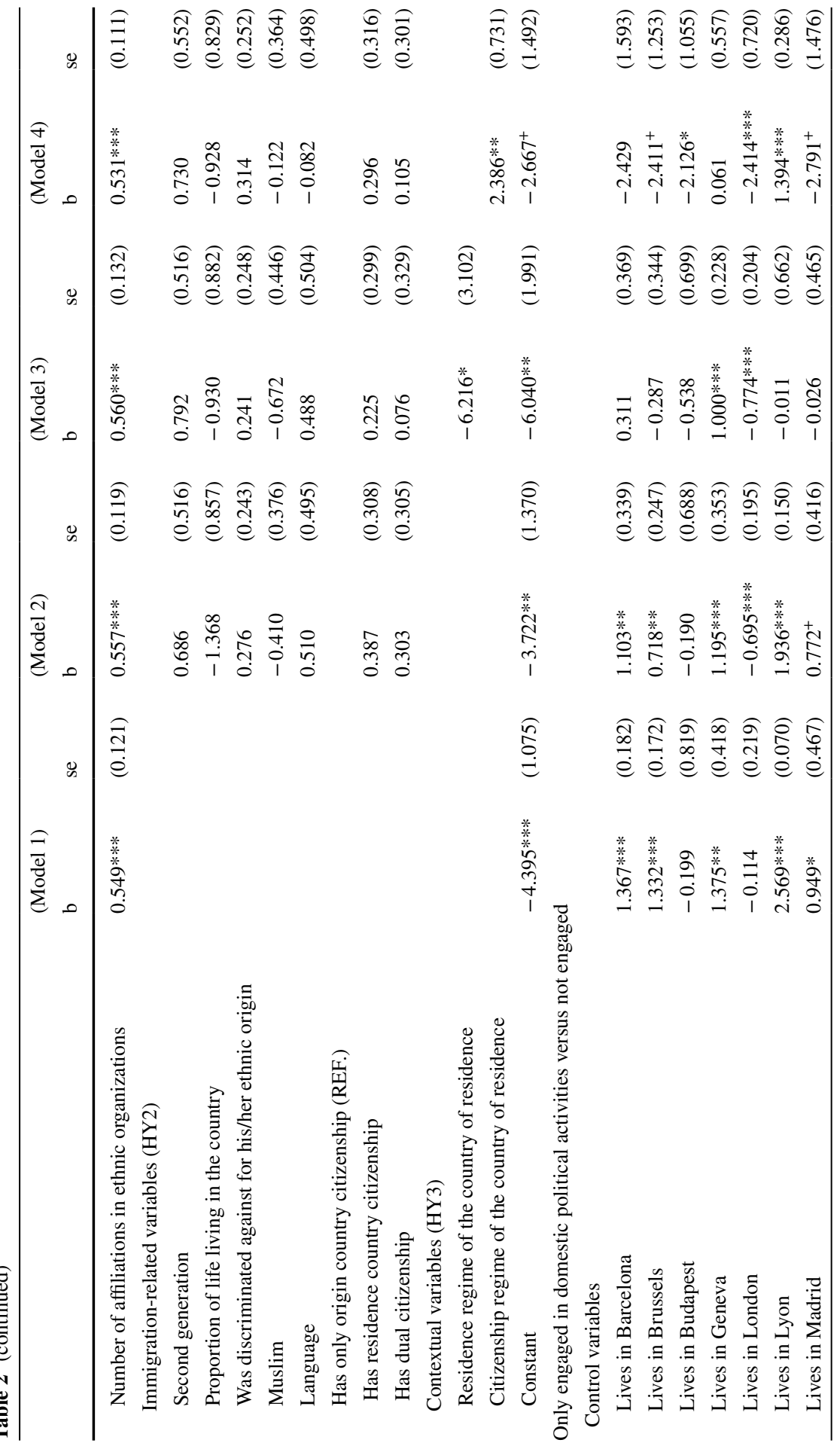




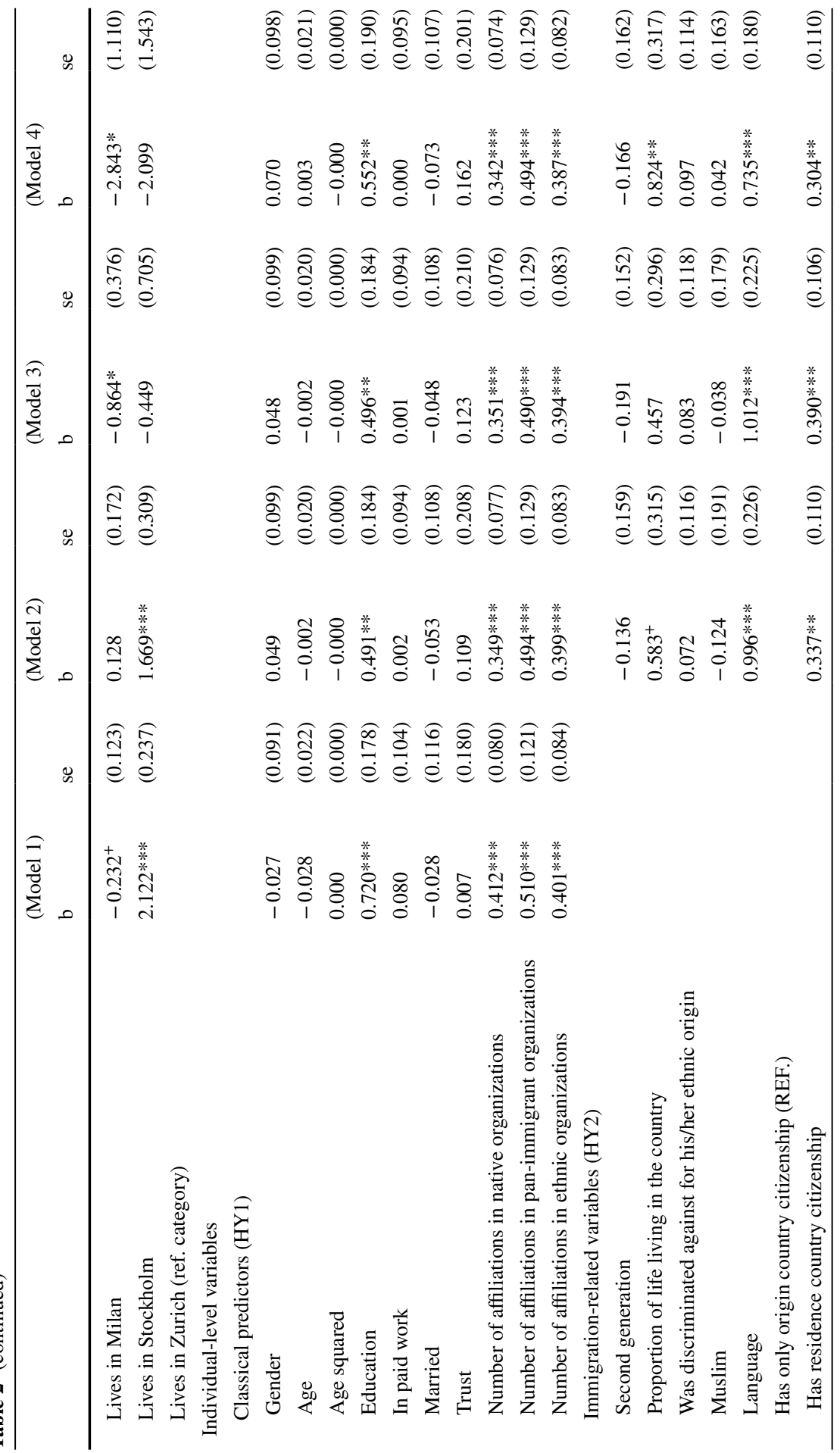

望 


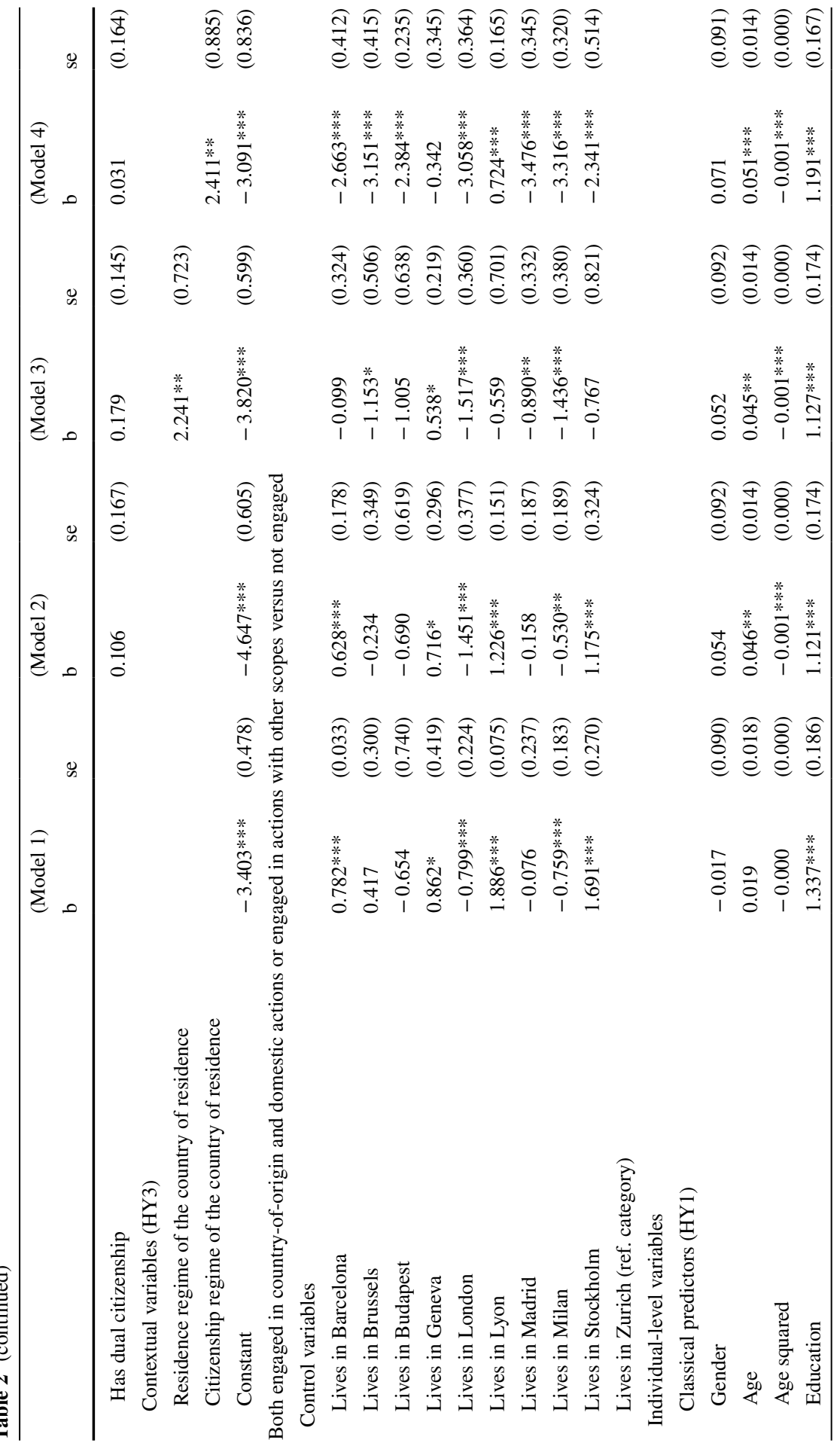




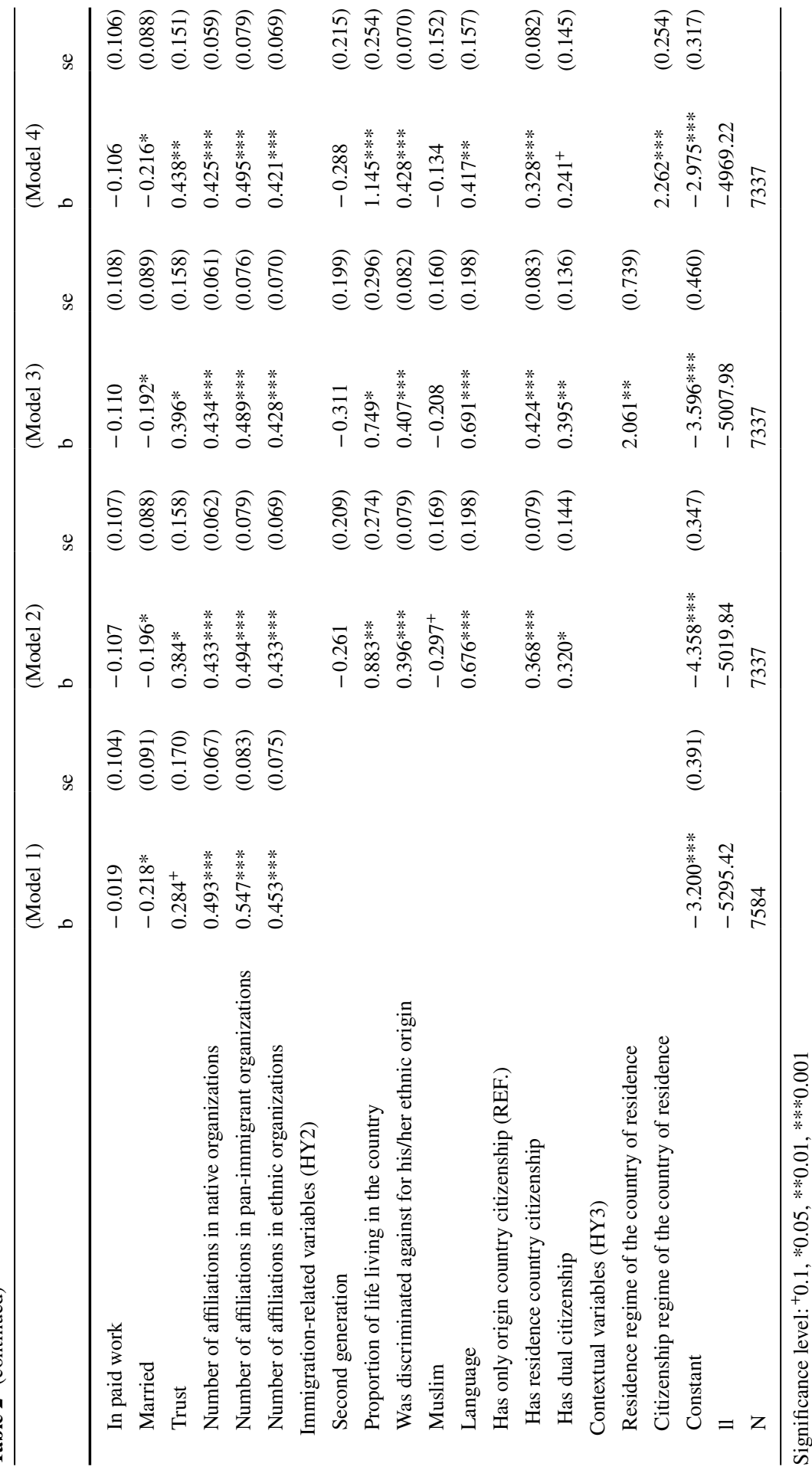

尔 
each variable, the reference category in the analyses is "having not engaged in any political activity". The results of the multivariable analysis are shown in Table 2. The latter illustrates results of the following nested models: model 1 shows the impact of the classical individual-level predictors of political behaviours (HY1); models 2 adds the individual-level variables related to the process of immigration (HY2); and models 3 and 4 add the contextual variables (HY3). Contextual variables are added separately due to high correlation. To interpret our results, we make reference to the upper part of the table, which includes the correlates of engagement in country-of-origin political activities, and to the middle part of the table, which refers to the results on the correlates of migrants' engagement in domestic activities. The bottom part of the table tests factors affecting engagement in both domestic and country-of-origin political activities or in other scopes of action and we do not discuss it.

Given that the effect of our independent variables may be different for migrants who are also citizens of the countries of residence (from now onwards simply citizens) and for migrant who do not hold the citizenship of the residence country, we re-elaborate analyses shown in the full models 3 and 4 of Table 2 on separate samples. We also elaborate separate analyses on first-generation migrants and on second generations. Online Appendix shows the results on the sample of migrants and second generations without citizenship of the country of residence (Table 2A), on the sample of citizens (Table 3A), on the sample of first-generation migrants (Table 4A) and on second generations (Table 5A). ${ }^{6}$

\section{Engagement in domestic and country-of-origin political activities in European cities}

Table 1 shows the distribution of engagement in political activities distinguishing actions with different scopes. The table shows that, with the exclusion of Lyon and Stockholm, we find very high rates of no participation in any activity across all cities. In average, $70.8 \%$ of all migrants sampled in the European cities analysed do not participate in any political activity. Looking at migrants who engaged, in average, $20.7 \%$ of migrants participated in both domestic and country-of-origin political actions or in activities which concerned actions with other scopes. If we specifically compare engagement in domestic activities only with engagement in country-of-origin political activities only, the former prevails. On average, only $1.2 \%$ of migrants and second generations engaged in country-of-origin activities, compared to $7.4 \%$ of migrants and second generations who engaged in domestic issues. Separate analyses further show that the percentage of individuals engaged in country-of-origin political activities only is even lower, below 1\%, among citizens and among second generations. Table 1A of Online Appendix shows that this pattern holds for most migrant groups across European cities as the percentage of migrants and second generations

\footnotetext{
${ }^{6}$ We cannot provide robustness checks by including analyses on single cities as many models on single cities do not converge given the low number of cases in specific categories of the dependent variable.
} 
who participated in country-of-origin activities is almost negligible for most groups (for findings emphasizing the limited use of transnational practices more broadly acknowledged, see Waldinger 2008, pp. 115-116; Fokkema et al. 2012). ${ }^{7}$

How can we explain migrants and second generations' likelihood to engage in domestic political issues only and in country-of-origin political issues only? The models in Table 2 test our hypotheses on the effect of individual and contextual factors which are likely to shape engagement in one or in the other type of action. The upper part of the table shows the results on engagement in country-of-origin political activities and the middle part of the table illustrates the results concerning engagement in domestic activities. Robustness checks in Tables 2A to 5A show that the findings in Table 2 tend to hold for the subsamples including migrants and second generations without citizenship (Table 2A) and first-generation migrants (Table 4A). They hold less for citizens of the residence country (Table 3A) and for second generations (Table 5A). ${ }^{8}$

Table 2 shows that classical predictors of political behaviour, when significant, have a positive effect both on the probability to engage only in country-of-origin political activities and on the probability to engage only in domestic political issues. The specific factors affecting one rather than the other type of action are, however, different. Married people are more likely to engage in country-of-origin political activities and this may be due to links with partners living in origin countries, although we cannot control for this variable. Socio-economic variables are hardly significant. As Table 3A shows, education plays a significant role in fostering both domestic and country-of-origin political activities among citizens only. Involvement in organizations works similarly for both types of action. However, their effect changes depending on the ethnic composition of organizations. Only engagement in ethnic organizations affects country-of-origin political activities. This suggests that, while we cannot equate engagement in ethnic organizations with engagement in country-of-origin politics, ethnic organizations are crucial in favouring engagement in country-of-origin political practices (Guarnizo et al. 2003; Itzigsohn and Villacrés 2008). Ethnic organizations are likely to provide those attachments, interests and identities bound to migrants' countries of origin which can lead to transnational engagement more easily than native organizations do. In addition, involvement in any organization, regardless of the ethnic composition, significantly affects engagement in domestic political activities (see the middle part of the table). These results clarify the integrative function of ethnic organizations in the politics of the residence countries too (Heath et al. 2013, p. 45; Pilati and Morales 2016). ${ }^{9}$ Trust

\footnotetext{
7 Our results differ from other studies on specific groups. For instance, Jaulin's study on external voting of Tunisian migrants find that external voting turnout in 2011 elections varied from 21.3 to $40.3 \%$ (Jaulin 2015, p. 9). However, the 2011 elections in Tunisia were the first held after Ben Ali's departure from Tunisia due to the eruption of protests in December 2010. Therefore, external voting during these elections may have been affected by such events.

8 The variables used in the models in Table 3A-5A are not the same as those included in the models 3 and 4 in Table 2 because of high correlation among some variables in the subsamples used.

9 The results on ethnic organizations are not significant among citizens (Table 3A) and among second generations (Table 5A).
} 
is only significant when we consider analyses limited to the sample of citizens (Table 3A)—whereby it decreases chances to engage in country-of-origin political activities - and in the sample limited to migrants and second generations with no citizenship of the residence country. In this case, it positively affects engagement in domestic political activities (cf. Table 2A). This suggests that individuals who lack the citizenship of the country of residence and engage in domestic political activities may somehow compensate the lack of citizenship with high level of trust in the institutions of the residence countries. Overall, when significant, classical predictors of political behaviour have a positive effect on migrants' probability to engage in political activities, regardless of the scope of the actions. This confirms hypothesis 1 despite only for the few variables discussed.

Focusing on the effect of immigration-related characteristics, results tend to show a positive effect of variables related to the socio-cultural integration on migrants' probability to engage in domestic issues (cf. the middle part of Table 2) (de Rooij 2012; Heath et al. 2013). In particular, fluency in the residence country language and being citizens of the residence country positively and significantly affect engagement in domestic political activities. This suggests that socio-cultural integration through language and citizenship induce migrants to feel and act as full political members of the country where they live. In contrast, none of the immigration-related variables significantly affects migrants' probability to engage in country-of-origin political activities. ${ }^{10}$ In light of these results, hypothesis 2 - on the impact of socio-cultural integration in domestic and country-of-origin activities-is confirmed for domestic politics but it is not for engagement in country-of-origin political activities.

We now turn to discuss the impact of contextual opportunities to understand whether individuals are led to engage in either one or the other scope of action due to different opportunities shaped by the contexts where they reside. Due to the low number of cases at level 2, we interpret these findings with caution as the role of contextual dimensions needs to be further explored with wider crosssectional surveys (cf. Ahmadov and Sasse 2016). Our results nonetheless clearly suggest the impact of contextual opportunities in shaping both migrants and second generations' action in domestic and in country-of-origin political issues, thus fully confirming hypothesis 3 . In particular, laws favouring access to citizenship and residence permits increase migrants' probabilities to engage in domestic political activities, confirming past studies on the impact of a context favouring the acquisition of citizenship and residence permits in shaping migrants' engagement in residence countries' politics (Gonzalez-Ferrer 2011; Morales and Pilati 2011). As migrants live in more open citizenship regimes, their probabilities to engage in political activities increase, regardless of the specific scope of action (cf. model 4

\footnotetext{
10 See, however, some changes in the effects of immigrant-related variables on domestic politics especially among citizens (Table 3A) and among second generations (Table 5A). The effects of immigrationrelated variables on country-of-origin political activities are less stable (cf. Tables 2A-5A).
} 


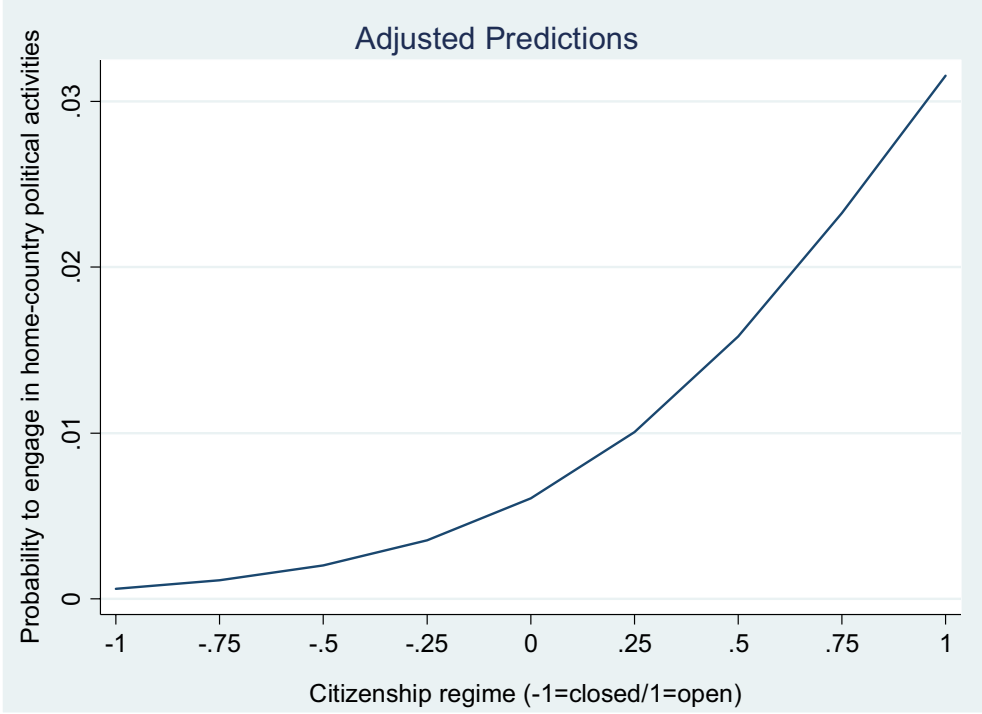

Fig. 1 Contextual effect of citizenship regime on engagement in country-of-origin political activities

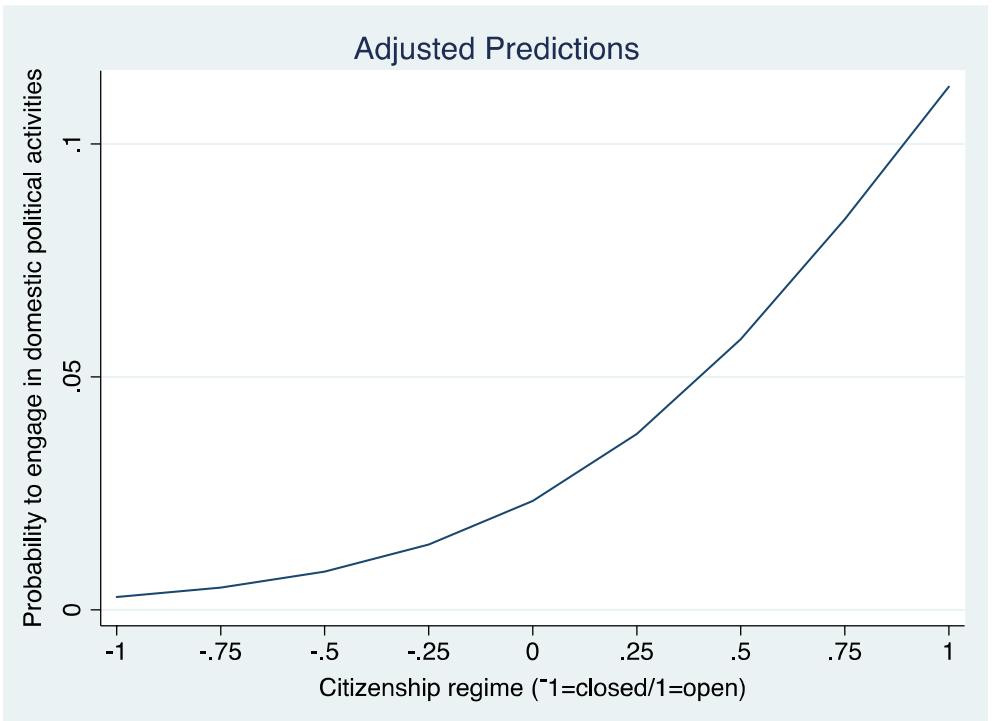

Fig. 2 Contextual effect of citizenship regime on engagement in domestic political activities

in Table 2). This is also clear from Figs. 1 and 2 illustrating the increase in the predicted probabilities to join domestic and country-of-origin political actions as the citizenship regimes opens (the score approximates +1$).{ }^{11}$ Migrants living in cities

\footnotetext{
${ }^{11}$ Table 3A shows that, as could be expected, the conditions shaping the citizenship regime do not affect citizens' likelihood to engage in political actions.
} 


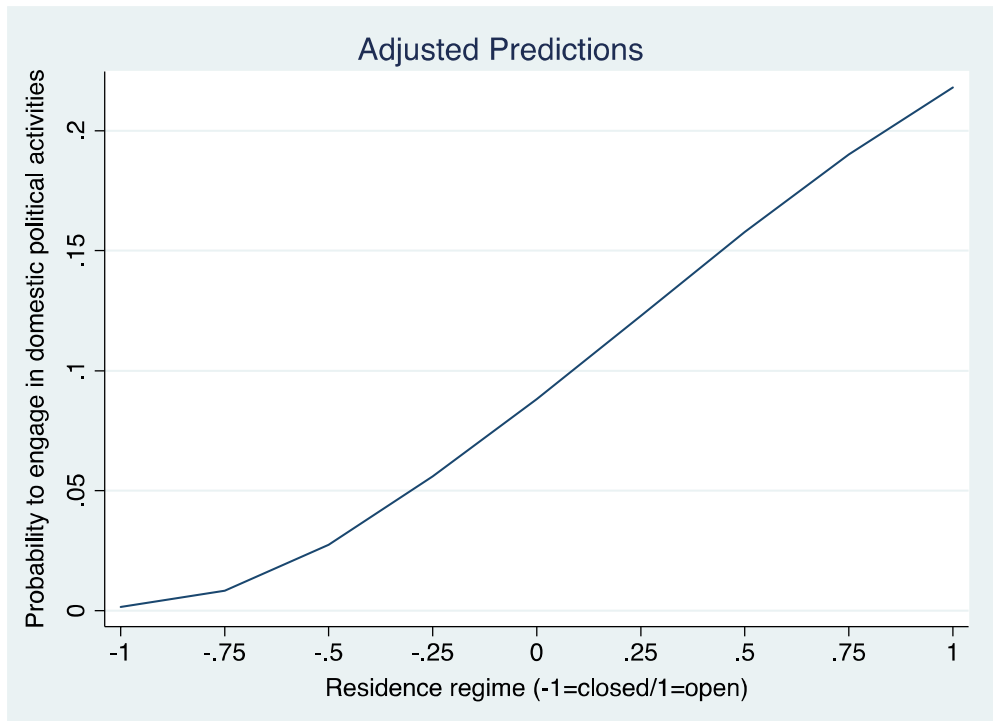

Fig. 3 Contextual effect of residence regime on engagement in domestic political activities

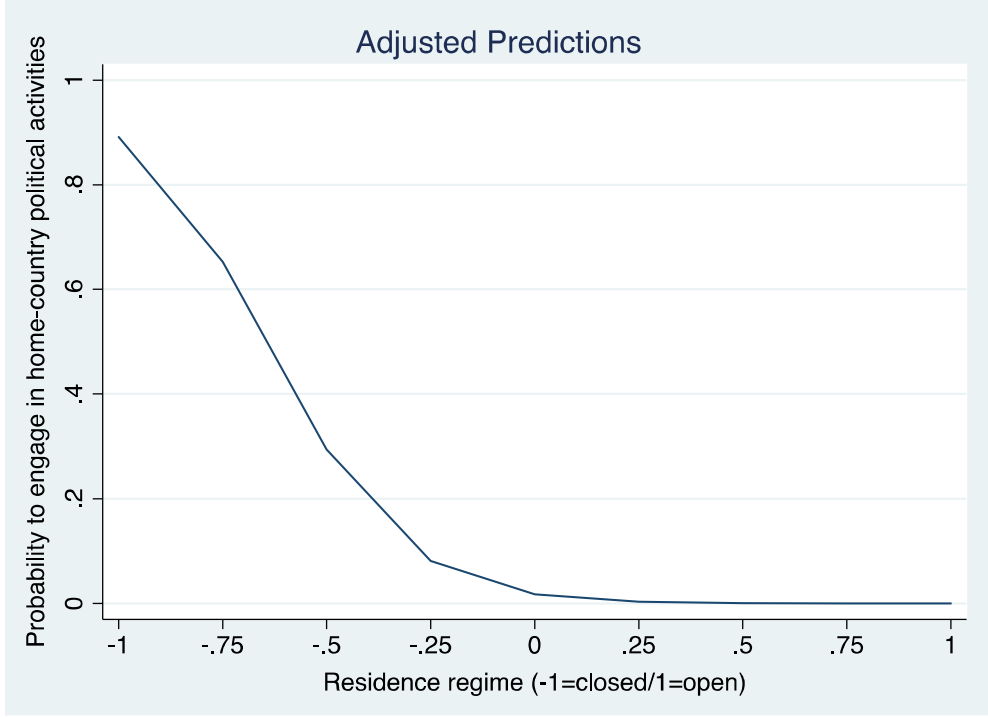

Fig. 4 Contextual effect of residence regime on engagement in country-of-origin political activities

where obtaining residence is easy have more chances to engage in domestic politics (cf. Fig. 3), but lower probabilities to engage in country-of-origin political activities. This is clear from Fig. 4 which shows that the probability to engage in country-of-origin political action decreases for migrants living in contexts where access 
to residence is easy while as residence regimes become close, the probabilities to engage in country-of-origin politics increase. This could be interpreted as a reaction to the few political opportunities of integration and the lack of stable conditions ensured by having a permit to stay experienced by migrants in such contexts.

\section{Conclusions}

This article had the aim of investigating levels of migrants' engagement in countryof-origin political activities and in domestic political activities. We did so by integrating insights from the literature on political transnationalism with the insights derived from the literature on migrants' political integration in the residence countries. Empirically, our study compared migrants' political engagement in actions with different scopes across ten European cities.

Our findings show that most migrants engage in both domestic and country-oforigin political activities and that, compared to engagement in domestic politics, involvement in country-of-origin political activities are extremely limited in most European cities. These results call for a reflection on the proliferation of the literature on transnationalism, a perspective which has become extremely popular, witnessing an impressive growth in the last decades, partly echoed by the debate between scholars addressing transnationalism as an "expansive phenomenon", with others being very critical of it (see Kivisto 2001). ${ }^{12}$ In this framework, results support those arguments suggesting that political transnationalism is compatible with a trajectory of political integration as has already been argued for other social and economic transnational dimensions (cf. Snel et al. 2006; Levitt and Jaworsky 2007; Mazzucato 2008). They also contrast those arguments advancing that migrants tend to build a "separate" society within their countries of residence. While transnationalism is a useful concept suggesting that actions in the country of residence need to be understood by considering what occurs in migrants' countries of origin, evidence shows that most migrants are more focused in making their lives work in their residence countries yet have attachments latent and active with their countries of origin, which ebb and flow over the life-course. ${ }^{13}$

The article also tried to clarify if migrants merely active in domestic issues differ from migrants active in issues related to their countries of origin because of different individual profiles or different opportunities of political integration in the residence country. The results show that, among the few individuals only engaged in domestic and those only engaged in country-of-origin activities, there are some slight differences in their profile. While individuals who are more likely to engage in country-of-origin political activities tend to be married migrants who are involved in

\footnotetext{
12 Just to provide a rough example of the proliferation of transnational studies, we looked at the number of times that the word "transnationalism" appeared in the abstracts of social science publications in the Sociological Abstracts database. The use of transnationalism steadily increased during the last two decades: between the 1 January 1980 and 31 December 1989, the word "transnationalism" did not appeared at all, between the 1 January 1990 and 31 December 1999 it appeared 113 times, while between 1 January 2000 and 31 December 2009 it quintuplicated as it appeared 567 times.

13 We thank a reviewer for this suggestion.
} 
ethnic organizations, individuals who are more likely to engage in domestic political actions tend to be involved in organizations regardless of their ethnic composition, have high proficiency in the language of the countries of residence and are citizens of the country of residence.

In turn, contextual opportunities (the POS) shape migrants and second generations' chances of political action regardless of their scope. Open citizenship regime significantly increases engagement in any type of political activity. In turn, an easy access to permits to stay increases engagement in domestic politics and decreases involvement in country-of-origin politics. Therefore, the latter seems a reaction to the lack of easy access to the permits to stay in the residence countries.

Overall, our comparative approach had indeed the advantage of positioning country-of-origin political activities vis-à-vis domestic political practices in a broad cross-city perspective. However, precisely because of the high number of cities and groups examined, we have not been able to supply any detailed experience of particular groups, and found it difficult to contextualize the experience of migrants in a specific city. This study needs therefore to be integrated by research addressing actors' experiences and their contexts in more depth, including more knowledge on migrants' context of emigration, looking, for instance, at the laws of migrants' origin countries relating to granting dual citizenship and external voting rights (JonesCorrea 2001; Levitt and de la Dehesa 2003; Faist and Kivisto 2007; Itzigsohn 2000; Smith 2008; Lafleur 2013; Ahmadov and Sasse 2016).

Acknowledgements Results presented in this paper stem from integrated datasets produced by the project "Multicultural Democracy and Immigrants' Social Capital in Europe: Participation, Organizational Networks, and Public Policies at the Local Level (LOCALMULTIDEM)". This project was funded by the European Commission under the 6th Framework Programme's Priority 7 "Citizens and Governance in a Knowledge-Based Society" as a STREP instrument (Contract No. CIT5-CT-2005-028802). The LOCALMULTIDEM consortium was coordinated by the University of Murcia (Dr. Laura Morales) and was formed by the University of Geneva (Dr. Marco Giugni), the University of Trento (Dr. Mario Diani), the University of Bristol (Dr. Paul Statham), the CEVIPOF-Sciences Po Paris (Dr. Manlio Cinalli), the MTAKI (Dr. Endre Sik) and the University of Manchester (Dr. Laura Morales). Funding for collection of the Brussels data was provided by the Fond d'Encouragement à la Recherche (FER) of the Université Libre de Bruxelles (ULB) and by the Scientific Impulse Mandate for professor Dirk Jacobs (ULB), granted by the national fund for scientific research (FNRS) for the project "Ethnic social capital and its impact on generalised trust and political participation among ethnic minority groups". We thank the anonymous reviewers for the useful insights provided on the previous drafts of the article.

Open Access This article is licensed under a Creative Commons Attribution 4.0 International License (https://creativecommons.org/licenses/by/4.0/), which permits use, sharing, adaptation, distribution and reproduction in any medium or format, as long as you give appropriate credit to the original author(s) and the source, provide a link to the Creative Commons licence, and indicate if changes were made.

\section{References}

Ahmadov, A.K., and G. Sasse. 2016. A voice despite exit the role of assimilation, emigrant networks, and destination in emigrants' transnational political engagement. Comparative Political Studies 49 (1): $78-114$. 
Aleksynska, M. 2011. Civic participation of immigrants in Europe: Assimilation, origin, and destination country effects. European Journal of Political Economy 27 (1): 566-585.

Bauböck, R. 2003. Towards a political theory of migrant transnationalism. International Migration Review 37 (3): 700-723.

Bauböck, R., and T. Faist. 2003. Diaspora and transnationalism: Concepts, theories and methods. Amsterdam: Amsterdam University Press.

Berger, M., C. Galonska, and R. Koopmans. 2004. Political integration by a detour? Ethnic communities and social capital of migrants in Berlin. Journal of Ethnic and Migration Studies 30: 491-507.

Bermudez, A. 2009. The transnational political practices of Colombians in Spain and the United Kingdom: Politics 'here' and 'there'. Ethnic and Racial Studies 33 (1): 75-91.

Bleich, E. 2009. Muslims and the state in the Post-9/11 West: Introduction. Journal of Ethnic and Migration Studies 35 (3): 353-360.

Bloemraad, I. 2006. Becoming a citizen in the United States and Canada: Structured mobilization and immigrant political incorporation. Social Forces 85 (2): 667-695.

Boccagni, Paolo, Jean-Michel Lafleur, and Peggy Levitt. 2015. Transnational politics as cultural circulation: Toward a conceptual understanding of migrant political participation on the move. Mobilities 11 (3): 444-463.

Brady, H.E., S. Verba, and K.L. Schlozman. 1995. Beyond Ses: A resource model of political participation. The American Political Science Review 89 (2): 271-294.

Carling, J., and K. Hoelscher. 2013. The capacity and desire to remit: Comparing local and transnational influences. Journal of Ethnic and Migration Studies 39 (6): 939-958.

Chaudary, A.R. 2017. Voting here and there: Political integration and transnational political engagement among immigrants in Europe. Global Networks. https://doi.org/10.1111/glob.12171.

Cinalli, M., and M. Giugni. 2011. Institutional opportunities, discursive opportunities, and the political participation of migrants. In Social capital, political participation and migration in Europe: Making multicultural democracy work?, ed. L. Morales and M. Giugni, 43-62. Basingstoke: Palgrave Macmillan.

Cinalli, M., and M. Giugni. 2016. Electoral participation of Muslims in Europe: Assessing the impact of institutional and discursive opportunities. Journal of Ethnic and Migration Studies 42 (2): 309-324.

de Rooij, E. 2012. Patterns of immigrant political participation: Explaining differences in types of political participation between immigrants and the majority population in Western Europe. European Sociological Review 28 (4): 455-481.

DeSipio, L. 2006. Transnational politics and civic engagement: Do home country political ties limit latino immigrant pursuit of US civic engagement and citizenship? In Transforming politics, transforming America: The political and civic incorporation of immigrants in the United States, ed. T. Lee, K. Ramakrishnan, and R. Ramirez, 106-126. Charlottesville: University of Virginia Press.

Eggert, N., and M. Giugni. 2011. The impact of religion on the political participation of migrants. In Social capital, political participation and migration in Europe: Making multicultural democracy work?, ed. L. Morales and M. Giugni, 219-237. Basingstoke: Palgrave.

Eggert, N., and K. Pilati. 2014. Networks and political engagement of migrant organizations in five European cities. European Journal of Political Research 53: 858-875.

Erdal, M.B. 2013. Migrant transnationalism and multi-layered integration: Norwegian-Pakistani migrants' own reflections. Journal of Ethnic and Migration Studies 39 (6): 983-999.

Erdal, M.B., and C. Oeppen. 2013. Migrant balancing acts: Understanding the interactions between integration and transnationalism. Journal of Ethnic and Migration Studies 39 (6): 867-884. https://doi. org/10.1080/1369183X.2013.765647.

Faist, T., and P. Kivisto. 2007. Dual citizenship in global perspective: From unitary to multiple citizenship. London: Palgrave Macmillan.

Fokkema, T., L. Lessard-Phillips, J. Bachmeier, and S. Brown. 2012. The link between the transnational behaviour and integration of the second generation in European and American Cities. Nordic Journal of Migration Research 2 (2): 111-123.

Goldring, L. 2002. The Mexican state and transmigrant organizations: Negotiating the boundaries of membership and participation. Latin American Research Review 37 (3): 55-99.

Gonzalez-Ferrer, A. 2011. The electoral participation of naturalized immigrants in ten European cities. In Social capital, political participation and migration in Europe: Making multicultural democracy work?, ed. L. Morales and M. Giugni, 63-86. Basingstoke: Palgrave. 
Guarnizo, L.E., A. Portes, and W. Haller. 2003. Assimilation and transnationalism: Determinants of transnational political action among contemporary immigrants. American Journal of Sociology 108 (6): 1211-1248.

Guarnizo, L.E., and M.P. Smith. 1998. The locations of transnationalism. In Transnationalism from below, ed. M.P. Smith and L.E. Guarnizo. New Brunswick: Transaction Publishers.

Heath, A.F., S.D. Fisher, G. Rosenblatt, D. Sanders, and M. Sobolewska. 2013. The political integration of ethnic minorities in Britain. Oxford: Oxford University Press.

Iskander, N. 2010. Creative state: Forty years of migration and development policy in Morocco and Mexico. Ithaca: Cornell University Press.

Itzigsohn, J. 2000. Immigration and the boundaries of citizenship: The institutions of immigrants' political transnationalism. International Migration Review 34 (4): 1126-1154.

Itzigsohn, J., and D. Villacrés. 2008. Migrant political transnationalism and the practice of democracy: Dominican external voting rights and Salvadoran home town associations. Ethnic and Racial Studies 31 (4): 664-686.

Jacobs, D., K. Phalet, and M. Swyngedouw. 2004. Associational membership and political involvement among ethnic minority groups in Brussels. Journal of Ethnic and Migration Studies 30: 543-559.

Jaulin, T. 2015. The geography of external voting: The 2011 tunisian election abroad, working paper series from economic to social remittances: An international overview. http://spire.sciencespo.fr/ hdl:/2441/3n8oro6t2a9s4ocaq54g729vb0/resources/1-jaulin2015-tsiworkingpaper.pdf.

Jones-Correa, M. 2001. Under two flags: Dual nationality in Latin America and its consequences for naturalization in the United States. International Migration Review 35 (4): 997-1029.

Just, A., and C.J. Anderson. 2014. Opinion climates and immigrant political action: A cross-national study of 25 European democracies. Comparative Political Studies 47 (7): 935-965.

Kastoryano, R., and M. Schader. 2014. A comparative view of ethnicity and political engagement. Аппиаl Review of Sociology 40: 241-260.

Kivisto, P. 2001. Theorizing transnational immigration: A critical review of current efforts. Ethnic and Racial Studies 24 (4): 549-577.

Koopmans, R., P. Statham, M.G. Giugni, and F. Passy. 2005. Contested citizenship: Immigration and cultural diversity in Europe. Minneapolis: University of Minnesota Press.

Lacomba, C. 2016. Mobilising abroad across ethnic lines: Home-country politics and immigrant political engagement in comparative perspective. Ethnicities 16 (1): 86-110.

Lacroix, T. 2014. Conceptualizing transnational engagements: A structure and agency perspective on (hometown) transnationalism. International Migration Review 48: 643-679.

Lafleur, J.-M. 2013. Transnational politics and the state: The external voting rights of diasporas. New York: Routledge.

Lafleur, J.-M., and M. Sánchez-Domínguez. 2015. The political choices of emigrants voting in home country elections: A socio-political analysis of the electoral behaviour of Bolivian external voters. Migration Studies 3: 155-181.

Landolt, P. 2001. Salvadoran economic transnationalism: Embedded strategies for household maintenance, immigrant incorporation, and entrepreneurial expansion. Global Networks 1 (3): 217-242.

Leal, D. 2002. Political participation by Latino non-citizens in the United States. British Journal of Political Science 32 (2): 353-370.

Levitt, P. 2001. The transnational villagers. Berkeley, CA: University of California Press.

Levitt, P., and R. de la Dehesa. 2003. Transnational migration and the redefinition of the state: Variations and explanations. Ethnic and Racial Studies 26 (4): 587-611.

Levitt, P., and N. Jaworsky. 2007. Transnational migration studies: Past developments and future trends. Annual Review of Sociology 33: 129-156.

Lien, P., M. Conway, and J. Wong. 2003. The contours and sources of ethnic identity choices among Asian Americans. Social Science Quarterly 84 (2): 461-481.

Martiniello, M., and J.-M. Lafleur. 2008. Towards a transatlantic dialogue in the study of immigrant political transnationalism. Ethnic and Racial Studies 31 (4): 645-663.

Mazzucato, V. 2008. The double engagement: Transnationalism and integration: Ghanaian migrants' lives between Ghana and the Netherlands. Journal of Ethnic and Migration Studies 34 (2): 199-216.

Mollenkopf, J., and J. Hochschild. 2009. Immigrant political incorporation: Comparing success in the United States and Western Europe. Ethnic and Racial Studies 33 (1): 19-38.

Morales, L. 2011. Conceptualising and measuring migrants' political inclusion. In Social Capital, political participation and migration in Europe: Making multicultural democracy work?, ed. L. Morales and M.G. Giugni, 19-42. Basingstoke: Palgrave Macmillan. 
Morales, L., E. Anduiza, B. Bengtsson, M. Cinalli, M. Diani, A. Örkény, and P. Statham. 2014. LOCALMULTIDEM and MDE individual survey (WP4) Dataset, 2004-2008. http://dx.doi.org/10.7910/ DVN/24987 Harvard Dataverse Network [Distributor] V2 [Version].

Morales, L., and M. Morariu. 2011. Is home a distraction? The role of migrants' transnational practices in their political integration into receiving country politics. In Social capital, political participation and migration in Europe: Making multicultural democracy work?, ed. L. Morales and M. Giugni. Basingstoke: Palgrave.

Morales, L., and K. Pilati. 2011. The role of social capital in migrants' engagement in local politics in European cities. In Social capital, political participation and migration in Europe: Making multicultural democracy work?, ed. L. Morales and M. Giugni, 87-114. Basingstoke: Palgrave.

Morales, L., and K. Pilati. 2014. The political transnationalism of Ecuadorians in Barcelona, Madrid and Milan: The role of individual resources, organizational engagement, and the mobilization context. Global Networks 14 (1): 80-102.

Mouw, T., S. Chavez, H. Edelblute, and A. Verdery. 2014. Binational social networks and assimilation: A test of the importance of transnationalism. Social Problems 61 (3): 329-359.

Mügge, L. 2016. Transnationalism as a research paradigm and its relevance for integration. In Integration processes and policies in Europe: Contexts levels and actors, ed. B. Garcés-Mascareñas and R. Penninx, 109-126. New York: Springer International Publishing.

Østergaard-Nielsen, E. 2002. Transnational politics: The case of Turks and Kurds in Germany. New York: Routledge.

Palacios, I., and L. Morales. 2013. LOCALMULTIDEM and MDE individual surveys (WP4) technical report. Version 1. Leicester: University of Leicester.

Pilati, K. 2016. Migrants' political participation in exclusionary contexts. From subcultures to radicalization. Palgrave Pivot Series Basingstoke: Palgrave-Macmillan.

Pilati, K. 2018. Gaps in protest activities between natives and individuals of migrant origin in Europe. Acta Sociologica 61 (2): 105-125.

Pilati, K., and L. Morales. 2016. Ethnic and immigrant politics vs mainstream politics: The role of ethnic organizations in shaping the political participation of immigrant-origin individuals in Europe. Ethnic and Racial Studies. 39 (15): 2796-2817.

Portes, A., C. Escobar, and A. Walton Radford. 2007. Immigrant transnational organizations and development: A comparative study. International Migration Review 41 (1): 242-281.

Portes, A., C. Escobar, and R. Arana. 2008. Bridging the gap: Transnational and ethnic organizations in the political incorporation of immigrants in the United States. Ethnic and Racial Studies 31 (6): 1056-1090.

Portes, A., L.E. Guarnizo, and P. Landolt. 1999. The study of transnationalism: Pitfalls and promise of an emergent research field. Ethnic and Racial Studies 22 (2): 217-237.

Portes, A., and R.G. Rumbaut. 2006. Immigrant America: A portrait. Berkeley, CA: University of California Press.

Pries, L., and Z. Sezgin. 2013. Cross border migrant organizations in comparative perspective. Basingstoke: Palgrave Macmillan.

Ramakrishnan, K.S. 2005. Democracy in immigrant America: Changing demographics and political participation. Palo Alto: Stanford University Press.

Ramakrishnan, K.S., and I. Bloemraad. 2008. Civic hopes and political realities community organizations and political engagement among immigrants in the United States and abroad. New York: Russell Sage Foundation.

Rim, K.H. 2009. Latino and Asian American Mobilization in the 2006 immigration protests. Social Science Quarterly 90 (3): 703-721.

Schiller, N.G., L. Basch, and C. Szanton Blanc. 1995. From immigrant to transmigrant: Theorizing transnational migration. Anthropological Quarterly 68 (1): 48-63.

Smith, R.C. 2008. Contradictions of diasporic institutionalization in Mexican politics: The 2006 migrant vote and other forms of inclusion and control. Ethnic and Racial Studies 31 (4): 708-741.

Snel, E., G. Engbersen, and A. Leerkes. 2006. Transnational involvement and social integration. Global Networks 6: 285-308.

Statham, P., and J. Tillie. 2014. The socio-cultural integration of Muslims in Western Europe: Comparative perspectives. Journal of Ethnic and Migration Studies 42: 2.

Tam Cho, W.K. 1999. Naturalization, socialization, participation: Immigrants and (non-) voting. The Journal of Politics 61 (4): 1140-1155. 
Uhlaner, C., B. Cain, and R. Kiewiet. 1989. Political participation of ethnic minorities in the 1980s. Political Behavior 11 (3): 195-231.

Van Bochove, M. 2012. Truly transnational. The political practices of middle-class migrants. Journal of Ethnic and Migration Studies 38 (10): 1551-1568.

Van Bochove, M., K. Rusinovic, and G. Engbersen. 2010. The multiplicity of citizenship: Transnational and local practices and identifications of middle-class migrants. Global Networks 10: 344-364.

van Deth, J.W. 2014. A conceptual map of political participation. Acta Politica 49: 349-367.

van Ingen, E., and T. van der Meer. 2015. Schools or pools of democracy? A longitudinal test of the relation between civic participation and political socialization. Political Behavior 38 (1): 83-103.

Verba, S., and N.H. Nie. 1972. Participation in America: Political democracy and social equality. New York: Harper and Row.

Verba, S., K. Schlozman, and H. Brady. 1995. Voice and equality: Civic voluntarism in American politics. Cambridge, MA: Harvard University Press.

Vertovec, S. 2004. Trends and impacts of migrant transnationalism. Centre on Migration, Policy and Society Working Paper No. 3, University of Oxford.

Voicu, B., and M. Comşa. 2014. Immigrants' participation in voting: Exposure, resilience, and transferability. Journal of Ethnic and Migration Studies 40 (10): 1572-1592.

Waldinger, R. 2008. Between "here" and "there": Immigrant cross-border activities and loyalties. International Migration Review 42: 3-29.

Waldinger, R. 2016. A cross-border perspective on migration: Beyond the assimilation/transnationalism debate. Journal of Ethnic and Migration Studies 43 (1): 3-17. https://doi.org/10.1080/13691 $83 \mathrm{X} .2016 .1238863$.

White, S., N. Nevitte, A. Blais, E. Gidengil, and P. Fourneir. 2008. The political resocialization of immigrants: Resistance or lifelong learning? Political Research Quarterly 61 (2): 268-281.

Katia Pilati is Assistant Professor at the Department of Sociology and Social Research (DSRS) at the University of Trento, Italy (PhD University of Trento, Department of Sociology and Social Research). Before joining DSRS, she was a Marie Curie fellow at the Department of Political Science at the University of Geneva (Switzerland) and a research fellow at the Université Libre de Bruxelles (Belgium). Her research interests include civic and political participation, immigration, social movements, social networks and political engagement in non-democratic contexts. Her recent publications appeared in European Journal of Political Science, Journal of Ethnic and Migration Studies, Global Networks, Mobilization and Ethnic and Racial Studies. She is the author of three books (Armando 2010; Palgrave Macmillan 2016; Il Mulino 2018).

Barbara Herman holds a PhD in Social and Political Sciences from the Université Libre de Bruxelles (ULB). She is a research associate at the Centre Bruxellois d'Action Interculturelle. Prior to this, she was a research associate at the Group of research on Ethnic Relations, Migration and Equality (GERMEULB). Her main research interests are political participation of migrants, social capital, socio-economical integration of refugees, integration policies and quantitative methodologies. Her work particularly focuses on migrants' careers in their host country. 